\title{
482
}

\section{REGULATION OF ECONOMIC ACTIVITY IN THE REGIONS AS A TOOL FOR INCREASING REGIONAL COMPETITIVENESS AND INVESTMENT ATTRACTIVENESS OF MUNICIPALITIES}

\begin{abstract}
Author analyzes scientific experience and literature in the field of assessing regional economy and regional development. In this research, the author tries to explore relation between state intervention and investment attractiveness of regions. The author proposes a new Regional Investment Index, which is an instrument for measuring business environment improvement and increase in investment attractiveness. This new Regional Investment Index is an instrument that can be used not only for analysis of economic indicators, but also for improvement of state policy at the regional level. The author develops Regional investment index in order to manage regional development and direction of investment processes. Regional investment index allows for a potential comparison of municipalities by combining different approaches and dimensions and thus becoming unique. The Russian index differs of the Regional investment index because the group of determinants is structured into two indexes. On the other hand, the Asian indexes are ones which are combined and refined in Regional investment index. The new Regional investment index is sophisticated, more
\end{abstract}

(C) Nikolay Tsonkov, 2020.

Tsonkov Nikolay, PhD, Associate Professor at the Department of Regional Development, University of National and World Economy, Sofia, Bulgaria. Email: kolio_tzonkov@abv.bg 
flexible, comprehensive and gives more opportunities for comparison at the level of local authorities and territories.

\section{Key words:}

Regional Investment Index, state intervention, regions, regional economy, regional development.

JEL: H83, R13, R58.

\section{Problem statement and literature review}

Regional economic research plays an important role in terms of revealing trends in the socio-economic development of regions and countries. There is a direct link between national and regional economic indicators and local economic development, including regional competitiveness. In turn, regional competitiveness is an engine for regional economic growth and attracting foreign direct investment (FDI). Therefore, there is a need to strengthen applied scientific economic research and observations in order to reveal the factors and interrelationships between regional economies. Such research will highlight the engines of growth and competitiveness that lead to increased investment attractiveness of the regions.

Therefore, it is necessary to study the regions, and in particular the municipalities in Bulgaria, in terms of their investment attractiveness and capacity to attract foreign direct investment (FDI). The aim of the study is to form a Regional investment index based on groups of indicators, which are ranked by severity and importance.

There are similar studies in the world scientific literature. One of these studies analyzes the state of Indonesia's regions. In this study, the authors assume that the investment attractiveness of the regions depends on two indices. In essence, it can be assumed that the regional investment index (RII), which is adopted in the present study, combines two sub-indices - an index of regional investment efficiency and an index of regional investment potential. These two indices are used by Indonesian scientists. The first shows how the attractiveness 
Regulation of economic activity in the regions as a tool for increasing regional competitiveness and investment attractiveness of municipalities

for investment is calculated in relation to the size of the economy. The second shows the factors that are expected to affect the attractiveness of a region to attract investors such as regional product, income per capita, inflation, exports, imports, unemployment, regional minimum wage, infant mortality, life expectancy and others (Kusumastuti \& Alhempi, 2020).

The second study, which is also relevant to the research topic, analyzes the state of the regions. It can be assumed that the Regional Investment Climate Index developed in this way has similarities with the Regional Investment Index proposed in the current development. The Regional Investment Climate Index was developed jointly by the Boston Consulting Group and the Agency for Strategic Initiatives of the Russian Federation. This index includes 44 factors and is intended to assist in the study of individual countries and regions (Nikitin et al., 2018).

In essence, business attractiveness indices have been a key tool in international economic development for decades. Analysts and researchers working in the field of economic development around the world find such indices useful in determining ways to improve the investment climate in their countries. But most of these indices have a critical limitation: they compare results across countries, despite many of the most important economic considerations being local in nature. The fact is that countries rarely grow all at once - often one region can be decades ahead of another part of the country.

To provide a more accurate picture, taking into account the specifics of individual regions, the Boston Consulting Group and the Russian Agency for Strategic Initiatives (ASI) have developed a tool for comparing the investment climate in a country in different regions. The scientists use this index for analyzing the investment climate. Experts can obtain information about regional development, including factors that are important for development. Such research models help the government to find the most correct and adequate solutions for improving the investment attractiveness of the country as a whole.

The methodology for developing the Regional Investment Climate Index focuses on four main business areas: regulatory environment, institutions that support business, infrastructure and resources, the strength of small and medium-sized businesses.

In each direction a number of individual parameters related to the state and local regulation of business conditions are studied. Examples of such regulatory instruments are business registration procedures, the effectiveness of governmental and non-governmental business support instruments, the quality and availability of labor, and the maturity of small businesses in the region. In practice, the model includes 44 indicators, combining statistics and data from studies and expert opinions. 


\section{Research methodology and formation of a regional investment index}

In our opinion, it is important to assess indicators such as the average time required for the business to connect to the electricity network and the average number of required procedures; the existence and quality of regional laws protecting investors' rights and the effectiveness of the regional institution responsible for regulatory impact analysis; the regional ratio of graduates of basic and secondary vocational educational institutions with experience in specific sectors (e.g. agriculture or construction) to the total number of employees in these sectors; the satisfaction of entrepreneurs with the the necessary level of expertise of work; the number of small enterprises (including individual entrepreneurs) per 1000 inhabitants in the region; the percentage of employees in small businesses (including individual entrepreneurs).

In the Russian study we could identify two stages. The first stage covers the evaluation of indicators. The second stage concerns the capacity of central and local institutions to manage the process not only of attracting investment but also of improving attractiveness, and is therefore also important.

Following the example of the developed model for monitoring and evaluation in Russia, a similar model for measuring the investment attractiveness of Bulgarian municipalities is proposed. Thus, the proposed Regional Investment Index aims not only to assess the investment attractiveness, but also the current state of the business environment on the basis of groups of indicators.

For the purpose of the research, a short survey was prepared. The main respondents were departments, companies, branch organizations, municipalities. The survey included ranking of groups of criteria, which covered territorial, social, economic, socio-economic and others, concerning the location, infrastructure and size, and the functions of the municipal center in the context of the territorialadministrative structure of the country. On this basis, the representatives of business, municipalities, branch organizations and others were to rank them in order of importance. Thus, the different groups of criteria acquired different weight in the formed complex regional investment index of the municipalities.

The groups of criteria are:

1. Demographic - population, types of demographic structure, etc.

2. Urbanization - number of dwellings, density, coefficient of urbanization, number of settlements, types of territories.

3. Infrastructure - accessibility, number of dwellings, construction, level of development, availability of modes of transport and adjacent infrastructure. 
Regulation of economic activity in the regions as a tool for increasing regional competitiveness and investment attractiveness of municipalities

4. Economic - investments in direct market access, European funds, sales revenues, production, number of companies, average salary.

5. Socio-economic $-\mathrm{km}$ of roads to population, $\mathrm{km}$ of water to population, access to drinking water and sewerage, electrification and others, budget revenues to population, time to connect to electricity, water and other networks, price of electricity, water, land

6. Settlement-administrative structure and rank and role of the municipality - number of outsourced institutions of the central government, rank of the municipality, state transfer, revenues from local taxes and fees, fees for building permits and time for issuance, number of employees in the municipality per 1000 inhabitants.

7. Natural-resource and ecological - availability of resources, location from the capital, from important economic and transport centers, geographical features.

Many of these indicators are directly related to the policy pursued by the state in the field of economy and regulation of socio-economic processes at the local level. They are reflected in the improvement of the business environment, regional competitiveness and investment attractiveness of the regions. The combined result of them and of effective state regulatory policy lead to regional economic growth and socio-economic development of the regions.

\section{Regulation of economic activity in the regions and regional competitiveness}

The regulation of economic activity and, more broadly, state regulation at all levels are the basis for creating a good business environment and attractiveness. Government tools for intervention in national and regional economies have a direct impact on regional development, raising the economic security index, the regional competitiveness index and improving the investment environment. This connection finds objective expression in the regional investment index. The index expresses the strong correlation that exists between the policy at the local level, the instruments of state intervention in the regional economy, the level of economic security, improving the attractiveness, illustrated in increasing the levels of investment. Of course, improving the attractiveness improves all economic indicators of the regions, which results in improved regional competitiveness.

Regional competitiveness is the ability of a region to offer an attractive and sustainable environment for living and working for companies and residents. The index was created in 2010 and is updated every three years. The Regional Competitiveness Index $(\mathrm{RCl})$ allows authorities in regions to monitor and assess their 
development over time and in comparison with other regions (European Structural and Investment Funds, n.d.).

The Regional Competitiveness Index $(\mathrm{RCl})$ measures the main competitiveness factors of 2010 for all NUTS-2 regions in the European Union. With more than 70 comparable indicators, the Index measures the region's ability to offer an attractive and sustainable living and working environment for companies and residents.

State and administrative regulation of economic activity is a fundamental question that has been discussed for decades. On the one hand, purely scientific and methodological reasons must be pointed out, which presuppose a distinction between state and administrative regulation; i.e. answer to the question of whether there is a difference between them. From another point of view, the management concepts can be analyzed, through which the social and economic effects of the regulation of the economic activity are realized.

State and administrative regulation are similar in terms of restricting or controlling economic entities in different sectors of the economy. At the same time, we could distinguish two main directions, through the prism of which the regulation of economic activity is carried out. In this regard, it can be argued that the state implements its policy and controls economic and market relations in two directions - economic and administrative. These two directions of regulation affect both independently and comprehensively the development of the regions.

State regulation is a kind of implementation of economic policy by the government through a variety of tools and measures. And the administrative regulation of economic activity is more concerned with the implementation of "prevention" and control over companies in the economy through the functioning of the state bureaucracy (public administration, expressed in the central and local executive bodies). The second type of state regulation is a projection and result of the application of administrative management within the public administration.

The emergence of new challenges in recent years has once again brought to the fore the importance of the state and its intervention in the economy. Changes in the environment also affect the factors that determine the functioning and development of the economy. The relationship between market competition and state regulation of economic dynamics is determined by the specific forces and conditions (Kovachev et al., 2009).

Depending on the objectives of the intervention, the state performs the following functions: distribution of scarce resources, income and national wealth; stabilization of the macroeconomic indicators - prices, the level of economic activity, unemployment, inflation, employment, income; regulation of private economic activity and investment activity in regions; government purchases and government procurement. In this way, the state and municipalities influence the 
Regulation of economic activity in the regions as a tool for increasing regional competitiveness and investment attractiveness of municipalities

development in the individual regions, creating favorable conditions for business and investment.

Based on the theory of systems management, regulation means the influence of a controlling subject on a controlled object, which must achieve a set of goals and expected results. From this point of view, state regulation is associated with directing social and economic processes to ensure the public interest and well-being. Despite the clarification, there is no precise definition of the term "state regulation". Most of the definitions reduce it to a political instrument with a specific practical expression in a certain area. State regulation encompasses the ideas of the rulers that apply to tax law, the use of fiscal instruments, including monetary policy, and, of course, the management of state property, through which economic relations can be regulated.

An important aspect of the regulation of economic relations is the rulemaking activity. The legislation not only regulates public relations, but also introduces rules and requirements for companies. These rules and requirements have their legal form in regulatory regimes at national and regional level. One of the authors who studies regulatory regimes is Andre Nijsen. He emphasizes the role of the state in maintaining social security, effective health care and a favorable environment, setting them as an essential priority of the state within its administrative functions and role (Nijsen et al., 2008). In order to meet the existing requirements, the state needs information about the regulations related to the actions of citizens and companies.

We could therefore accept regulation as a policy instrument that uses a variety of intervention measures in the economies of individual regions. States implement this policy in different ways. Dina Eerma (2008) recognizes that regulation is the use of normative instruments to achieve socio-economic and political goals.

According to some authors, regulation takes place in three areas - social, procedural and economic (Chittenden et al., 2002). The state policy is connected with regulation in all indicated spheres. Social regulation guarantees great public benefits and goods, such as health care, security, transport, environmental protection and others. Procedural regulations cover the administrative mechanism of the state - administration and required documents, fees, immigration rules and procedures, public procurement and required statistical information. Economic regulations support a certain trade and financial framework and market. The described regulations determine the regulatory framework in the country and the regions.

Regulatory barriers have been studied by various authors (Geroski, Parker and Sted, Church and Weir, Bitzenis and others). However, all emphasize the importance of regulations for economic agents who have entered a new market. Their significance stems from the fact that they are introduced by the state through its actions and are guaranteed through legislative measures and their 
implementation. Regulatory barriers cover both the legislation and regulations, and the economic policy of the country (Kotsios, 2010).

Nijsen's theoretical formulation is very common. According to him, administrative barriers (regimes) represent the costs imposed on business when fulfilling information obligations established by the state (Fig. 1).

Figure 1

Different business costs, arising from implementation of regulations



Source: adapted by the author on the basis of Nijsen et al. (2008)

Based on this view of the nature of state and administrative regulation, it can be concluded that administrative regulation is part of state regulation and is a set of state activities to implement regulatory requirements, rules and standards through a set of laws, decrees, regulations and sub-normative acts and ordinances, as well as the activities for implementation and control for observance of all rules and documents.

Two indices are mainly used to assess administrative regimes and the regulatory environment. In terms of business opportunities, the index of economic freedom is used. It includes the following components - business, company registration, licensing, hiring of workers, real estate registration, borrowing, protection of investor interest, payment of taxes, participation in international trade, implementation of contracts in practice and closing a company. The other 
Regulation of economic activity in the regions as a tool for increasing regional competitiveness and investment attractiveness of municipalities

main criterion is the so-called cost model, which generally calculates the costs of the business - a standard cost model. This model calculates the indicator of administrative barriers.

$$
A B=T * Q * F * P
$$

$T$ - time spent on the information obligation

$Q$ - number of business agents and citizens

$\mathrm{F}$ - annual frequency

$\mathrm{P}$ - hourly rate (for business)

These two indicators are key when considering more effective administrative regulation of economic activity in Bulgaria. On this basis, one can find opportunities for better regulation and how it affects the development of individual regions in the country. In practice, the opportunities for higher efficiency are lower costs and better functioning of the administrative system. In this sense, better regulation, the functioning of the administration and the efficiency of regulatory regimes create favorable conditions for business and investment. The improvement of the business environment as a result of the regulation by the state and the municipalities improves the regional competitiveness and attractiveness of the regions. Proof of this is the improvement of economic indicators and the Regional Investment Index.

\section{Conclusions}

The development of a Regional Investment Index will not only enrich the accumulated scientific experience, but will offer another model for measuring and assessing the regional competitiveness and investment attractiveness of the regions. The model will help to improve state and local economic regulations and investment activities of the state to improve the business environment and its attractiveness.

Local economic development is unthinkable without active government policy and regulation. Regional economic growth is reflected in the socioeconomic cohesion and connectivity of the regions, including the improvement of the capacity and results in the regions. The model, which is offered, in many respects borrows scientific thesis of Michael Porter (2008). The so-called Porter's diamond describes the microeconomic business environment, consisting of four factor determinants of competitiveness. The first factor includes geographical conditions, natural resources, human resources, physical infrastructure, administrative infrastructure and innovation infrastructure. The second determinant contains the available supporting industries such as credit schemes, transport, packaging, consulting services for SMEs. The third area includes the conditions of demand and opportunities in the existing market. And the fourth factor consists of 
the conditions of competition such as barriers to the entry of a new company. These four factors are interrelated and influence each other. One of the highlights of local economic development is the increasing pressure on the urgency of improving competitiveness and knowledge, technology and innovation in local economic development.

State intervention in the economy and regions is important and creates conditions for development. Government policies and regulations should be aimed at stimulating the development of new technologies, innovation, improving the educational environment, strengthening the business-education link, publicprivate partnerships, investment in applied research, knowledge accumulation and skills development. In this way, the active state policy will improve and increase the regional competitiveness and investment attractiveness of the regions.

\section{References}

1. Chittenden, F., Kauser, S., \& Poutziouris, P. (2002). Regulatory burdens of small business: A literature review. Department of Trade and Industry, Small Business Service.

2. Eerma, D. (2005). Application of the regulation theory in economy. Reportspapers of the XIII scientific and educational conference (Tartu - Varska, 30. June - 2. July 2005), 219-227. http://www.mattimar.ee/publikatsioonid/ majanduspoliitika/2005/2005.pdf

3. European Structural and Investment Funds. (n.d.). The EU regional competitiveness index 2019 [Data set]. European Commission. https://cohesiondata.ec.europa.eu/stories/s/Regional-Competitiveness-Index2019/363v-4uq6/

4. Kotsios, P. (2010, March). Regulatory barriers to entry in industrial sectors. International Conference on International Business Proceedings.

5. Kovachev, A., Kamenov, K., Gateva, N., \& Asenov, A. (2009). Business environment and sustainable development [in Bulgarian]. Svishtov.

6. Kusumastuti, S. Y., \& Alhempi, R. R. (2020). Regional Investment Performance Index and Regional Investment Potential Index as Regional Competitiveness Index in Indonesia. International Journal of Management Sciences and Business Research, 9(1), 34-42. https://zenodo.org/record/ 3702063\#. X3hdWWgzbIW

7. Nijsen, A., Hudson, J., Müller, C., Van Paridon, K., \& Thurik, R. (Eds.). (2008). Business regulation and public policy: The costs and benefits of compliance (Vol. 20). Springer Science \& Business Media. 
Regulation of economic activity in the regions as a tool for increasing regional competitiveness and investment attractiveness of municipalities

8. Nikitin, A., Chupsheva, S., Kustarin, I., Boutenko, V., Polunin, K., \& Stepanenko, A. (2018, January 12). Helping regions grow faster and grow better. Boston Consulting Group. https://www.bcg.com/industries/publicsector/helping-regions-grow-faster-grow-better

9. Porter M. (2008). Competitive Advantage: Creating and Sustaining Superior Performance (Kindle Ed.). Free Press; 1st Edition.

The article was received on June 14, 2020. 